\title{
Project Kinang: A Gem In Advancing The Individual Innovativeness Of Pre-Service Secondary School Teachers
}

\author{
Romiro G. Bautista ${ }^{\mathrm{a} *}$, Agaton P. Pattalitan, $\mathbf{J r}^{\mathrm{b}}$ Michael A. Mayoya $^{\mathrm{c}}$, Michael C. Bagay ${ }^{\mathrm{d}}$ \\ ${ }^{\mathrm{a}, \mathrm{c}}$ Office of the University Director for Instruction, Quirino State University, Philippines \\ ${ }^{\mathrm{b}, \mathrm{d}}$ Secondary Education Department, College of Teacher Education, Quirino State University-Diffun Campus, Philippines \\ corresponding author: ${ }^{2}$ romiro.bautista@qsu.edu.ph
}

Article History: Received: 10 November 2020; Revised 12 January 2021 Accepted: 27 January 2021; Published online: 5 April 2021

\begin{abstract}
Innovativeness is the idea that describes an individual's tendency to adopt and adapt innovation earlier than other members of their niche and the society where they live in. This study aimed to determine the individual innovativeness of preservice secondary school teachers as affected by Project KINANG. Employing the Mixed Method with the One Group Pretest Posttest Research design and Phenomenology as points of inquiry to a group of 89 Pre-service Secondary School Teachers, the following were found: the respondents were made early adopters, early and late majority from their initial states as early and late majority and laggards; the statistical treatment showed significant results on the respondents' innovation index in their pretest and posttest; the effect size of Project KINANG was of medial effect; and the Project KINANG interacted better among males, Biology majors, and age group 21-22 although no significant results were posted through ANOVA. Moreover, the preservice secondary school teachers vouched that the Project KINANG provided them learning experiences and encounters that were morale boosting and motivating; hastening task management, teaching effectiveness, curiosity, and innovation; inspiring the pre-service secondary school teachers to become researchers; improving the pre-service secondary school teachers' communication skills; and heightening collaboration that provided them avenues to learn new ideas. Owing to the aforementioned results, it is concluded that the provisions of Project KINANG improved the innovativeness of the pre-service secondary school teachers.
\end{abstract}

Keywords: Project KINANG, Individual Innovativeness, Pre-service Secondary School Teachers, Action Research.

\section{Introduction}

The advent of educational technologies and advanced paradigms of innovative psychology in the workplace has directed professionals to come across their disposition and to reinvent their innovativeness by adopting new information, practices, and standards within their niche and social systems (Bautista et al., 2018; Anderson, 2010; Anderson et al., 1998). Innovation, in this sense, is underscored as the idea, practice, or object that is perceived as new by an individual or other unit through adoption and adaption (Rogers, 2004). As a result, individuals as rational beings employ mechanisms in adopting and adapting various changes in their social systems. This includes their adaptations to various changes that may affect their efficacy as agents of innovations (Yuksel, 2015; Davis et al., 2010; Oliver \& Goerke, 2008; Nutley et al., 2002).

Individual innovativeness centers the idea of being adoptive and adaptive to changes through risk-taking which is not common to everybody. Hence, innovativeness is described as the tendency to adopt and adapt innovation earlier than other members of their niche and the society where they live in. As applied in the diverse and dynamic workplace, professionals especially teachers need to update themselves in the realms of individual innovativeness - the climate that puts every professional to become receptive towards change particularly to their workplace' standpoints and practices (Celik, 2013; Cocklar, 2012; Soffer et al., 2010; Ali, 2003).

The crux is: innovation which is intertwined with the inevitable change demonstrates positive attitude towards change. Teachers must enthusiastically deal change as a learning avenue that will craft their classroom efficacy on infusing innovations among their coworkers and students. Hence, this study deals on the determinant of the effects of Project KINANG on the state of individual innovativeness of pre-service secondary school teachers. Moreover, it also documents their experiences and encounters on the provisions of the implemented Project KINANG.

\subsection{Objectives of the Study}

This study was designed to determine the effect of Project KINANG on the innovativeness of Pre-service Secondary School Teachers.

Specifically, it aimed to:

1. determine the mean innovativeness scores of the respondents in the pretest and posttest; 
2. determine the mean gain score on the innovativeness of the respondents when grouped by profile;

3. evaluate the significant difference on the mean innovativeness scores of the respondents in their pretest and posttest;

4. evaluate the significant difference on the mean gain score on the innovativeness of the respondents when grouped by profile;

5. evaluate the effect size of Project KINANG on the innovativeness of the respondents; and

6. document the learning experiences and encounters of the informants on the provisions of Project KINANG.

\subsection{Theoretical Framework}

Innovation-Decision Process Theory. This theory is based on time and five distinct stages. The first stage is knowledge. Potential adopters must first learn about the innovation. Second, they must be persuaded as to the merits of the innovation. Third, they must decide to adopt the innovation. Fourth, once they adopt the innovation, they must implement it. Fifth, they must confirm that their decision to adopt was the appropriate decision. Diffusion results once theses stages are achieved.

Individual Innovativeness Theory. This theory is based on who adopts the innovation and when. It was noted that individual innovativeness is apportioned at the individual level in a variety of external or social conditions that may accelerate or slow the diffusion process:

1. Whether the decision is made collectively by individuals or by a central authority;

2. The communication channels used to acquire information about an innovation, whether mass media or interpersonal;

3. The nature of the social system in which the potential adopters are embedded (as identified by its norms) and the degree of interconnectedness; and

4. The extent of change agents' promotion efforts advertisers, development agencies, among others.

Classroom teachers as adopters of change and innovation are explicated in Bandura's Social Learning Theory and Self -efficacy Theory. According to Bandura's Social Learning Theory (1977), the behavior of individuals in the midst of this radical change is intertwined with their cognitive processes. One of the main tenets of this theory is that individuals hold stronghold beliefs to their capabilities to organize and execute courses of actions relative to managing prospective radical situations (Ali, 2017; Su Eroz, 2017; Hammond et al., 2011). Hence, the personal beliefs of individuals rationalize their mental acumen in demonstrating their capacity to adopt and adapt new policies that might affect the veracity of their work and works under the perspectives and emphases on the diffusion of innovation (Bautista et al., 2018; Nutley et al., 2002). This in turn is based on peoples' behavior being strongly related to their attitude towards a certain course of action and decision. People form attitudes by systematically deliberating on any information that they have about the behavior being considered. In return, attitude may result from the individuals' beliefs about the consequences of a particular behavior and their evaluation of those beliefs (Ajzen, 1991; Parlar \& Cansoy, 2017).

Moreover, self-efficacy as postulated in Self-efficacy Theory covers the individual's personal beliefs and capacity to manage instructional activities such as planning, organizing, and achieving goals to a desired level (Celik, 2013). Self-efficacy, as may be attributed in the teaching profession, is the personal-internal motive that accounts every professional's commitment to instructional capabilities that are autonomy-supportive and positive for student-engagement and achievement outcomes amidst the newness of the idea that may come across their routine as professionals (Kilicer \& Odabasi, 2010; Eggen \& Kauchak, 2008; Parminter \& Wilson, 2003). This attribution may exude every individual to enthusiastically and willingly adopt and adapt changes and innovations. Hence, innovativeness impinges a potential role in shaping the mindset of every individual to a greater sense of commitment and enthusiasm in the teaching profession.

\section{Methodology}

\subsection{Design}

This study used the Mixed Method employing the One Group Pretest Posttest Research design and Phenomenology as points of inquiry to 89 Pre-service Secondary School Teachers. A pretest was employed to determine the initial innovativeness of the respondents. After which, the Project KINANG was employed. After the project was completely implemented, a posttest on the respondents' state of innovativeness was conducted. Qualitative data were also gathered through interviews. Thematic analysis was employed to further analyze the data.

\subsection{The Intervention Program - Project Kinang}

The Project KINANG stands for Keen and Innovative scaffolding in Ne Plus Ultra Sessions through Active and Notable Groupings. 
Keen and Innovative scaffolding. The first leg of the Project was a seminar workshop on innovative and effective teaching in the $21^{\text {st }}$ century. This was geared towards uplifting their spirit to become innovative and effective $21^{\text {st }}$ century teachers. The seminar was offered in a dogmatic manner. The second leg of the project was an orientation program with specialized topics on classroom innovations and teacher empowerment on December 4, 2018. The third leg of the project is the Pinning Ceremony to further empower their vista on being innovative teachers. The fourth leg of the project is a visitation program with Focus Group Discussion (FGD). This brought proper scaffolding among the respondents in their activities and performances in the field. This was designed to address the needs of the respondents. Guided mentoring was done.

$\mathrm{Ne}$ plus ultra Sessions. Learning Action Cell (LAC) sessions were implemented during the course of the study: session with the school heads and session with the proponents of the study. Each LAC Session was designed to empower the respondents to become innovators - adopters of change in the dynamic classroom. Their sessions with their school heads centered on the best practices that they want to introduce and practice in their own unit. Usually, it was facilitated by their School Principals and District Supervisors.

On the other hand, there are two sessions conducted by the proponents: General sessions to the respondents and Advanced sessions to the Team Leaders (TLs). The general session is composed of general and introductory sessions on Lesson Study (LS) or the Research Lesson (RL), Action Research, writing a publishable research article, doing the viva voce, among others while the TLs' session is an advanced session. The TLs are chosen based on a certain rubric as they will lead their groups' learning sessions and in crafting their academic requirements and activities. All these and more were centered on enlivening their vista of being innovative.

Active and Notable Groupings. Groupings were done in a conjecture manner - respondents are brought to active learning situations with functional unit and support group. A team headed by a prominent leader who can facilitate change and innovation. Moreover, they are trained to facilitate a Research Lesson which they can cascade among their teammates.

\subsection{Respondents/Informants of the Study}

For the Quantitative Analysis, this study employed the 89 Pre-service Secondary School Teachers who underwent the Student Teaching program for the SY 2018-2019. However, it made use of purposive sampling in the qualitative analysis on the informants' experiences and encounters on the provisions of project KINANG: two informants were chosen from each station composed of the team leader and a member. The member is nominated by the team leader who religiously participated the activities set forth in the study.

Table 1. Profile of the Respondents

\begin{tabular}{|c|c|c|c|}
\hline \multicolumn{2}{|l|}{ Profile } & \multirow{2}{*}{$\begin{array}{l}\text { Frequency } \\
10\end{array}$} & \multirow{2}{*}{$\begin{array}{l}\text { Percent } \\
11.20\end{array}$} \\
\hline Major & Biological Science & & \\
\hline & English & 12 & 13.50 \\
\hline & Filipino & 21 & 23.60 \\
\hline & Mathematics & 10 & 11.20 \\
\hline & TLE & 36 & 40.40 \\
\hline & Total & 89 & 100 \\
\hline \multirow[t]{3}{*}{ Sex } & Male & 21 & 23.60 \\
\hline & Female & 68 & 76.40 \\
\hline & Total & 89 & 100 \\
\hline \multirow[t]{4}{*}{ Age } & $19-20$ & 61 & 68.50 \\
\hline & $21-22$ & 19 & 21.30 \\
\hline & $23+$ & 9 & 10.10 \\
\hline & Total & 89 & 100 \\
\hline
\end{tabular}

Presented in Table 1 is the profile of the respondents as to sex, age, and major field of study. It shows that most of the respondents are females as teaching is seen to be a program dominated by females. Moreover, they are 
mostly regular students and dominated by the TLE majors. In the case of this study, TLE is the dominating course because there was a need for it when the K-12 program was implemented.

\subsection{Research Instrument}

The instrument used in this study was adopted from Hurt, Joseph, and Cook (1977); albeit old, indicators still hold to be true as perceived by the proponents in assessing individuals' orientations towards change. The instrument had been found to be highly reliable and the predictive validity is good: an alpha of .89. In the current study, the alpha is .92 .

The questionnaire has two groups of items: Group 1 is composed of items that elicit their positive characteristics on innovation while Group 2 is composed of items that elicit their negative characteristics. The standardized range in determining their innovation index is shown in Table 2.

Table 2. Indices of Individual Innovativeness

\begin{tabular}{|l|c|}
\hline Categories of Individual Innovativeness & Score \\
\hline Innovators & $81+$ \\
\hline Early Adopters & $69-80$ \\
\hline Early Majority & $57-68$ \\
\hline Late Majority & $46-56$ \\
\hline Laggards/Traditionalists & $45-$ \\
\hline
\end{tabular}

The following is the scoring guide in determining their innovation index as adopted from the study of Kicer and Odabasi (2010):

1. Add the scores for items 4, 6, 7, 10, 13, 15, 17, and 20;

2. Add the scores for items 1, 2, 3, 5, 8, 9, 11, 12, 14, 16, 18, and 19;

3. Determine the innovativeness index. In general, people who score above 68 and considered highly innovative and people who score below 64 are considered lowly innovative.

$$
\text { Innovation Index }=43+\text { Step } 2 \text { score }- \text { Step } 1 \text { score }
$$

\subsection{Data Treatment}

Data were processed through frequency, mean, percent, t-test, eta, and thematic analysis.

Frequency. This was used to determine the number of respondents falling in a certain variable, e.g., sex, age, civil status, educational attainment, division, position, and the categories of innovativeness.

Mean. This was used to determine the average age and the general innovation index of the respondents when grouped by profile.

Percent. This was used to present the proportion of respondents on the different categories of innovativeness when grouped by profile.

t-test. This was used to determine significant differences on the innovativeness of the respondents in the pretest and posttest conducted and when the respondents were grouped by sex.

ANOVA. This was used to determine significant differences on the innovativeness of the respondents when grouped by age and major.

Eta. This was used to determine the effect size of Project KINANG on the innovativeness of the respondents.

Thematic Analysis. This was used to determine the recurring themes on the experiences of the informants on the provisions of Project KINANG. Document trail was also employed to determine the veracity of the claims of the informants.

\section{Results}

1. Quantitative Analysis on the Effects of Project KINANG on the Individual Innovativeness of Pre-service Secondary School Teachers 
Table 3. Mean Score on the Innovativeness of the Respondents

\begin{tabular}{|l|l|l|}
\hline Pretest & & Posttest \\
\cline { 3 - 3 } 57.85 & Mean Innovation Index & 59.66 \\
\hline Early Majority & Interpretation & Early Majority \\
\hline
\end{tabular}

Presented in the table are the pretest and posttest results on the innovation index of the respondents. It shows that the respondents had general indices of 57.85 and 59.66 in the pretest and posttest, respectively. Moreover, the readings of the two indices are early majority. It can be noted that there is a minimal margin (1.81) on the mean difference of the two indices. This means that there are other factors which are not included in the study that might had affected the concordances of the respondents towards their innovativeness.

Table 4. Frequency on the Innovation Categories of the Respondents

\begin{tabular}{|l|l|l|l|l|}
\hline Types of Innovation & Pretest & Posttest & \% Increase & $\%$ Decrease \\
\hline Early Adopters & 0 & 2 & $200 \%$ & - \\
\hline Early Majority & 52 & 66 & $126.92 \%$ & - \\
\hline Late Majority & 36 & 21 & - & $58.33 \%$ \\
\hline Laggards/Traditionalists & 1 & 0 & - & $100 \%$ \\
\hline Total & 89 & 89 & & \\
\hline
\end{tabular}

As it can be gleaned in Table 4, the respondents were generally early majority, late majority, and laggards in terms of their innovativeness as determined in their pretest results. However, respondents were made early adopters, early majority, and late majority as determined in their posttest results. Noticeably, $200 \%$ and $126.92 \%$ increase to early adopters and early majority, respectively. On other hand, $58.33 \%$ and $100 \%$ decrease to late majority and laggards or traditionalists. Therefore, the study through the Project KINANG made early adopters and eliminated laggards among the respondents.

Table 5. t-test on the Innovation Index of the Respondents

\begin{tabular}{|l|l|l|l|}
\hline & t-test & p-value & Decision \\
\hline Innovativeness Index & -3.208 & $.002 *$ & Reject Ho \\
\hline Eta2 value $=.573 ;$ Interpretation=Medium effect \\
\hline
\end{tabular}

*significant at .05 level

As it is shown in the table, there is a significant difference on the innovation index of the respondents during the pretest and the posttest conducted. The t-value, together with the p-value of the results, indicates significant results which led to the rejection of the null hypothesis which states that there is no significant between the innovation index of the respondents in the pretest and posttest. Likewise, the eta square on the treated data indicates medium effect on their innovation index. This means that some other important factors might not have been considered in the study which may impinge great impact on the respondents' concordances on innovation.

Table 6. t-test on the Innovation Mean Gain Scores of the Respondents when grouped by Sex

\begin{tabular}{|l|l|l|l|l|l|}
\hline \multirow{3}{*}{$\begin{array}{l}\text { Mean Gain Score on the } \\
\text { innovativeness of the respondents }\end{array}$} & \multicolumn{2}{|l|}{ Mean Gain Score } & t- & p- \\
value & value & Decision \\
\cline { 2 - 7 } & 1.90 & 1.78 & .094 & .925 & $\begin{array}{l}\text { Failed } \\
\text { Reject Ho }\end{array}$ \\
\hline
\end{tabular}

Presented in the table are the t-test results on the mean differences on the mean innovation gain scores of the respondents when grouped by sex. It shows that the male respondents afforded higher gain score with a mean difference of .28; although this suggests a negligible margin. Furthermore, it shows that the study failed to establish enough evidences to reject the null hypothesis as indicated by the t-value and p-value of the study. Hence, a comparable innovation state among the respondents is assumed.

Table 7. ANOVA on the Innovation Mean Gain Scores of the Respondents when grouped by Age

\begin{tabular}{|l|l|l|l|l|l|l|}
\hline & \multicolumn{3}{|l|}{ Mean Gain Score } & $\begin{array}{l}\text { F- } \\
\text { value }\end{array}$ & p- value & Decision \\
\cline { 2 - 7 } & $19-20$ & $21-22$ & $23+$ & & \\
\cline { 2 - 7 } $\begin{array}{l}\text { Mean Gain Score on the } \\
\text { innovativeness of the } \\
\text { respondents }\end{array}$ & 1.84 & 2.21 & .78 & .220 & .803 & $\begin{array}{l}\text { Failed to } \\
\text { reject Ho }\end{array}$ \\
\hline
\end{tabular}

Presented in the table are the F-test results on the mean differences on the mean innovation gain scores of the respondents when grouped by age. It shows that the age group 21-22 had the highest gain score: a mean difference of .37 and 1.43, respectively for the age groups 19-20 and 23+. Moreover, it shows that the study failed to 
establish enough evidences to reject the null hypothesis as indicated by the F-value and p-value of the study. Hence, a comparable innovation state among the respondents is assumed.

Table 8. ANOVA on the Innovation Mean Gain Scores of the Respondents when grouped by Major

\begin{tabular}{|c|c|c|c|c|c|c|c|c|}
\hline \multirow{3}{*}{$\begin{array}{l}\text { Mean Gain Score } \\
\text { on the } \\
\text { innovativeness of } \\
\text { the respondents }\end{array}$} & \multicolumn{5}{|c|}{ Mean Gain Score } & \multirow{2}{*}{$\begin{array}{l}\text { F- } \\
\text { value }\end{array}$} & \multirow{2}{*}{$\begin{array}{l}\mathrm{p}- \\
\text { value }\end{array}$} & \multirow[t]{2}{*}{ Decision } \\
\hline & English & Math & Bio & Fil & TLE & & & \\
\hline & 1.00 & 3.60 & 3.80 & 1.19 & 1.39 & .824 & .514 & $\begin{array}{l}\text { Failed to } \\
\text { reject Ho }\end{array}$ \\
\hline
\end{tabular}

Presented in Table 8 are the F-test results on the mean differences on the mean innovation gain scores of the respondents when grouped by major. It shows that the study failed to establish enough evidences to reject the null hypothesis as indicated by the F-value and p-value of the study. Hence, a comparable innovation state among the respondents is assumed.

On the other hand, it shows that Biology majors had the highest mean gain score: mean difference of 2.80, .20, 2.61, and 2.41, respectively for English, Mathematics, Filipino, and TLE, although no significant differences between and among the mean gain score are posted.

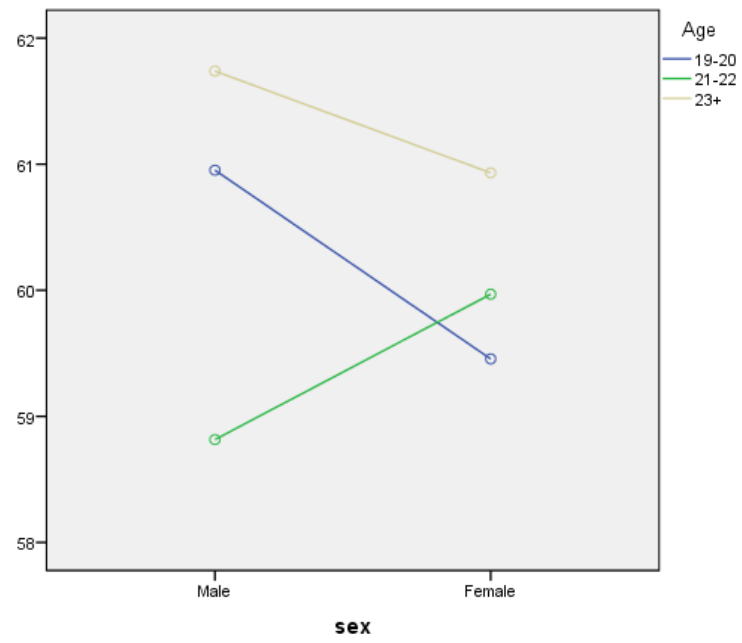

Figure 1. Interaction of Project KINANG on the Individual Innovativeness of the Pre-service Teachers between Sex and Age

Results in Figure 1 show that Project KINANG interacted better among the male-respondents for the age groups 19-20 and 23+ than their female counterparts. On the other hand, it interacted better among the females for the age group 21-22. This implies that the respondents of the study are heterogenous in nature with specific needs and educational standpoints.

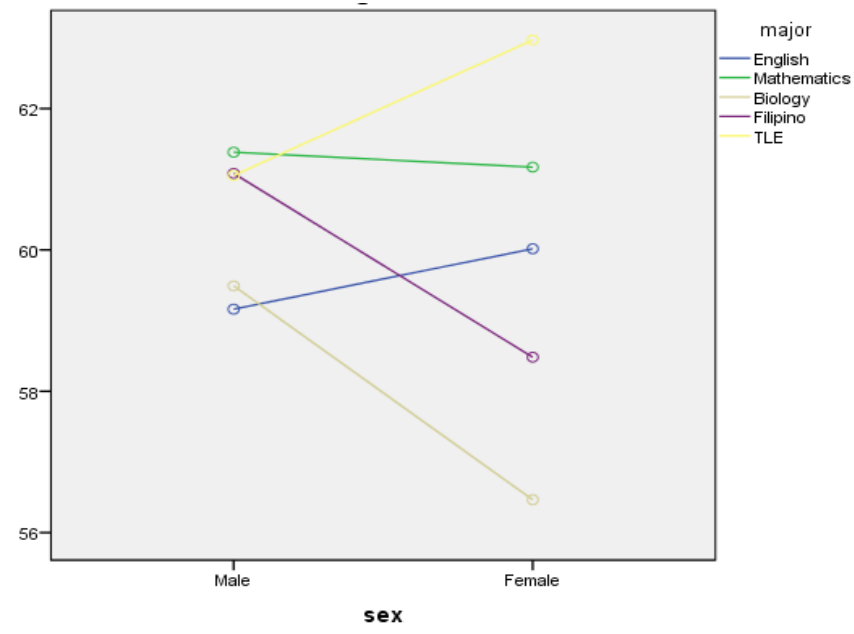

Figure 2. Interaction of Project KINANG on the Individual Innovativeness of the Preservice Teachers between Sex and Major Field of Studies 
Presented in Figure 2 is the interaction of Project KINANG to the respondents' sex and major field of studies. It shows that the female TLE and English majors afforded better affordances than their male counterparts. On the other hand, the male Filipino and Biology respondents did better results than their female counterparts while the Mathematics majors show no great margin for comparison as evidenced in Tables 7 and 8.

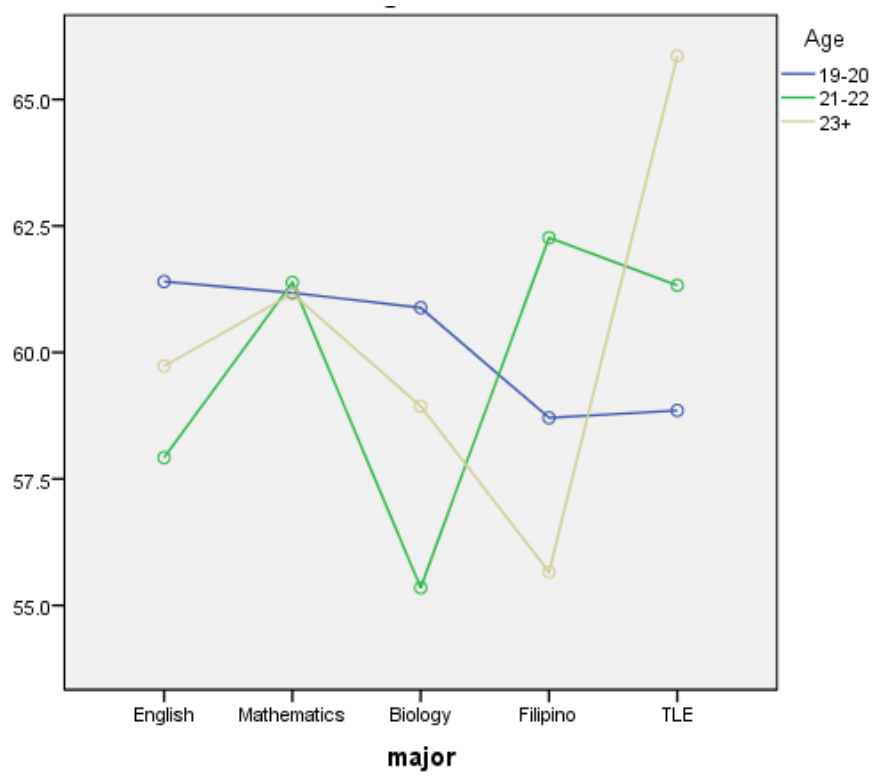

Figure 3. Interaction of Project KINANG on the Individual Innovativeness of the Preservice Teachers between Major Field of Studies and Age

Presented in Figure 3 is the interaction effects of Project KINANG on the individual innovativeness of the respondents. It shows that the project interacted the most to the age group 23+ among TLE majors, 21-22 for Filipino and Mathematics, and 19-20 for Biology and English. This implies that the project interacted well between the age and major field of the respondents.

2. Qualitative Analysis on the Experiences and Encounters of the Pre-service Secondary School Teachers on the provisions of the Project KINANG

2.1 Perceived Effects of the Pinning Ceremony

Morale boosting. This is the act of providing a reinforcement that will strengthen the desired outcome. In this study, the College of Teacher Education (CTE) expects that its students will showcase a performance at par during their Student Teaching program which is reinforced by a Pinning Ceremony, firstly implemented in the university.

The following transcripts qualify the claim of the study that the conducted Pinning Ceremony of the Project KINANG boosted the morale of the informants to undergo student teaching:

Informant 3. “... yung parang an-sarap ng feeling... di ba nga e first time na ginawa ang Pinning Ceremony at sa batch pa namin. Ang sarap ng feeling na ipi-pin ka as a teacher....”

"It was great! The Pinning Ceremony is new in the university and it was conducted firstly in our batch. The feeling was great as I was pinned as a teacher..."

Informant 2. “... yung pinning ceremony noon e kung baga eh nag-boost sa akin na.... ay nandito na pala ako, eto na yun... yung haharapin ko na ang actual teaching..."

"The Pinning Ceremony boosted me to face the actual teaching..."

Informant 9. “...Naging confident akong ma-deploy kasi through it e na-boost yung energy ko..."

"It made me confident to be deployed. It boosted my energy..."

Motivation. The learners' motivation impinges the extent of learning they are to engage and exude. This, however, is influenced by their emotional states, beliefs, interests, goals, and habits. The provisions of the Project KINANG were to set the mood of the pre-service secondary school teachers to undergo the Student Teaching program.

The following transcripts qualify the claim of the study that the conducted Pinning Ceremony of the Project KINANG motivated the informants to undergo student teaching:

Informant 6. “... ang sarap ng feeling na ipi-pin ka as a teacher... parang mamo-motivate ka na mag-undergo ng PT and to act as a teacher talaga kasi may Pinning Ceremony...",

"To be pinned as a teacher is something. I felt motivated to undergo PT and to act as a real teacher..." 
Informant 5. “... Yung sa pinning e mas na-motivate ako kasi parang pre-graduation na ito kasi nandun na kasama mo si mother, teachers, and classmates. Mas na-motivate kami na kaya namin ito. We will show our best, our knowledge, our intelligence as we were deployed..."

"I was motivated in the pinning because it was as if it is a pre-graduation ceremony as my mom, teachers, and classmates were there. We were motivated to showcase our best, our knowledge, our intelligence as we get deployed..."

Feeling of being ready and excited to teach. The individuals' affordances to showcasing their potentials depend on their beliefs and personal states. These beliefs and personal states which can be realized from a series of action sequence advances the individual's learning from their academic experiences and encounters. This study provided start-up activities that pole-vaulted their interest to go further in their Student Teaching program.

The following transcripts qualify the claim of the study that the conducted Pinning Ceremony of the Project KINANG made the informants ready and excited to undergo student teaching:

Informant 7. “.... Feeling mo eh ready ka na. feeling ko sa Pinning e ina-acknowledge ka ng university na ready kana na magturo or $i$-apply yung natutunan for 3 years in college na hindi na lang demo-demo sa mga kaklase mo... ganon..."

"I feel that I am ready. During the Pinning, the university acknowledged my readiness to teach or to apply all my learnings for 3 years in the college. This time, it's no longer a peer teaching..."

Informant 1. “...parang graduation na yong nangyari na yon ... parang na-excite na magturo...”

"It's just like we had our graduation. I was excited to teach..."

Informant 8. “... mixed emotions noon. Excited na ako na masaya ganon. Yun nga kasi haharapin ko na ang actual teaching... yung parang legit na talaga na pupunta na kami sa field..."

"I had mixed emotions. Excited and happy because I will be on my actual teaching - a legitimate act of sending us to the field..."

Feeling of being proud. Performances of individuals are preceded by a function of the connections learned. Making them realized their potentials is an extra-mile for them to exude better in their Student Teaching program.

The following transcripts qualify the claim of the study that the conducted Pinning Ceremony of the Project KINANG made the informants proud to undergo student teaching:

Informant 1. "yong parang kwan.... Sasabihin mo sa sarili mo na proud ka... kasi narating mo ito... parang graduation na yung nangyari na yon..."

"I am proud of myself because I have reached this far. It's as if we had our graduation..."

Informant 4. “... parang kwan... yung pakiramdam na kaya mo nang magturo tapos ipi-pin pa sa yo yung emblem ng school ng mga school officials. I feel proud na kaya ko na...”

"I felt that I can teach. Moreover, the emblem of the university is pinned to me by the university officials. I feel proud..."

Informant 10. “...nagbigay ito ng challenge sa akin. Naramdaman ko na at the end of this semester ay gagraduate na ako. Proud ako kasi kasa-kasama ko sina Papa at Mama...”

"I was challenged. I felt that I will be graduating at the end of this semester. I am also proud as I was with my Dad and Mom..."

2.2 Effects of the Intervention Program

2.2.1 On Teaching and Learning

Task management. The provisions of the Project KINANG include a practice associated to an improved craft and excellent performances. Efficacy, which is a desired effect, is coined from a number of practiced behavior that belongs to a similar sequence of actions.

The following transcripts qualify the claim of the study that the provisions of the Project KINANG made the informants to manage their tasks properly:

Informant 1. “... sa pagtuturo kasi e maraming trabaho, papers... paper works na madami. So nai-prepare kami na i-handle yung mga yon. Marami kasi siyang (pertaining to the subject professor) in-implement sa $\operatorname{amin} . . . "$

"There are many paper-works in teaching but we are prepared to handle these. Our teacher implemented many interventions for us to be prepared for these tasks..."

Informant 7. “... ayun so naging conscious kami sa tasks namin. Na-manage naman namin yung mga tasks kahit na marami kaming assignment sa coop namin. Yun pala yung purpose ni sir don sa mga iyon (pertaining to the interventions made) ..." 
"We were conscious about our tasks. We managed our tasks despite the numerous assignments we had from our cooperating teacher. We realized the purposes of our teacher in having all those programs..."

Informant 2. “... naging instrument siya para ma-improve namin yung mga sarili namin sa future tasks namin as a teacher lalong-lalo na sa research. Kadami kayang assignment at paper works tapos may research pa..."

"It was an instrumental to improve ourselves for our future tasks as a teacher especially in research. We had a lot of assignments, paper-works, and of course, the action research..."

Informant 3. "... through the collaborative works and group discussions namin at sharing na rin e natuto akong $i$-handle nang mabuti ang mga tasks ko specially sa paggawa ng LP at research...”

"Through our sharing in our group discussions and collaborative works, I learned to handle my tasks especially in doing LPs and research..."

Teaching effectiveness. Shaping the cognitive structure of the learners is sending them to state where they can apply their learned subsumptions - a state where learners associate their learning from a previous schema. In this study, the informants are made to wonder on the various aspects of teaching.

The following transcripts qualify the claim of the study that the provisions of the Project KINANG made the informants to come across learning towards teaching effectiveness:

Informant 4. “... nakatulong siya sa akin (pertaining to the intervention programs) na ma-improve ko yung pagtuturo ko lalo na sa strategies ko. Nakatulong yung tasks ko kay sir upang mapabuti, mapaganda ang pagtuturo ko. Naka-innovate ako na makabuo ng strategy para ma-involve ko ang mga students ko..."

"It improved me a lot especially on my teaching strategies. My tasks with our professor hasten my teaching for the better. I came to innovate strategies on how to involve my students..."

Informant 5. “... nagbigay yun ng way para mas ma-embody namin talaga yung pagtuturo - na-heighten yung pagtuturo namin. Mag-iisip ka talaga ng way upang masolusyonan yung problem ...”

"It made us embody teaching as it heightened our everyday teaching tasks. It will really make you think to come up with solutions..."

Informant 6. “... naging curious ako sa mga bagay-bagay na pwedeng i-research para mapabuti ko ang pagtuturo ko..."

"I was made curious about things that I can research to improve my teaching..."

Informant 9. “...Kung mamahalin mo lang ang pagtuturo at paresearch-research e hindi ka mahihirapan bagkus magbibigay ito ng inspirasyon na i-aim yung magandang pagtuturo..."

"Your tasks as a teacher will not be as difficult as one thinks if you will love teaching and doing research. Instead, you will be inspired to aim teaching better..."

\subsubsection{On Conducting Action Research}

Curiosity and Innovation. Motivation precedes the individual's ability to innovate from a combinatorial curiosity. In this sense, the learners are prepared to become innovators in providing solutions to problems that may arise from the classroom teaching and learning. In this study, they are trained to conduct an action research as a means to improve the quality of their teaching performances.

The following transcripts qualify the claim of the study that the provisions of the Project KINANG made the informants to become curious and innovative in teaching:

Informant 6. “... naging curious ako sa mga bagay-bagay na pwedeng i-research para mapabuti ko ang pagtuturo ko..."

"I was made curious about things that I can research to improve my teaching..."

Informant 4. “... nakatulong siya sa akin (pertaining to the intervention programs) na ma-improve ko yung pagtuturo ko lalo na sa strategies ko. Nakatulong yung tasks ko kay sir upang mapabuti, mapaganda ang pagtuturo ko. Naka-innovate ako na makabuo ng strategy para ma-involve ko ang mga students ko..."

"It improved me a lot especially on my teaching strategies. My tasks with our professor hasten my teaching for the better. I came to innovate strategies on how to involve my students..."

Informant 10. “... Yung sa akin kasi e talagang ginawa ko. Na-challenged kasi ako na gumawa ng totoong research. Kaya nag-isip ako ng magandang innovation...”

"I was challenged; so, I innovated..."

Informant 5. “... nagbigay yun ng way para mas ma-embody namin talaga yung pagtuturo - na-heighten yung pagtuturo naming. Mag-iisip ka talaga ng way upang masolusyonan yung problem..." 
"It made us embody teaching as it heightened our everyday teaching tasks. It will really make you think to come up with solutions..."

Inspired to become a researcher. The motivation of an individual ranges from their experiences that reinforces their attitude. In this study, a start-up activity that honed their interest in research was provided. It is expected that after undergoing the provisions of the Project KINANG, the informants are transformed lovers of research.

The following transcripts qualify the claim of the study that the provisions of the Project KINANG inspired the informants to become researchers:

Informant 3. “... oo. Nainspired ako na maging researcher. Hindi napili yung research ko di ba pero mas nainspire ako na ano pa ang pwede kong gawin para sa susunod e ok na ang research ko..."

"Yes! I am inspired to become a researcher. I am inspired to do more although my paper was not chosen..."

Informant 9. “...na-encourage ako na mag-research pa kasi ginawa ko yung intervention (maganda yun). Tapos nanalo pa ako...”

"I was encouraged to do more researches. My intervention was good and I won..."

Informant 8. “... na-inspire talaga ako na mag-research kasi sa research marami ang pwedeng mangyari sa yo gaya ng mga achievements ng mga sikat na teachers (smiles); so gumawa ako ng isa at nanalo. Di pa ito ang huli...

"I am inspired to become a researcher by the achievements of some prominent teacher-researchers. I made one and I won. Definitely, this is not the last..."

Informant 7. “... yung sa action research expo e nag-build ng confidence ko na humarap sa panel katakot kaya kasi mga batikan na researchers. Mixed emotions ako buti na lang naitawid ko. Naging independent ako at na-inspired lalo na mag-research..."

"The Research Expo built my confidence for I stood before the research experts. I became independent and inspired to do more researches..."

Improved Communication skills. Perfecting a craft is a matter of practicing it through a number of potential learning sessions. This study provided avenues where the informants may build their skills particularly in their written and oral communication skills because a teacher regardless of his specialization needs to exemplify competence in communication.

The following transcripts qualify the claim of the study that the provisions of the Project KINANG improved the communication skills of the informants:

Informant 1. “... sa experience ko e masasabi kong na-improved yung communication skills ko kasi mag-isa na ako. Natuto akong magsulat nang mag-isa at mag-rason nang mag-isa..."

"My experiences improved my communication skills. I learned to write and do the defense alone..."

Informant 2. “... I learned how to communicate effectively which I can use later lalong-lalo na sa research. Natuto akong mag-sulat nang maayos..."

"I learned how to communicate effectively which I can use later especially in research. I learned how to write effectively..."

\subsubsection{On Group Lesson Planning}

Heightened Collaboration. This study holds the belief on the synergy of group works where members are made to be team-players. In effect, the pre-service secondary school teachers are exposed to team activities where collaborative sessions are inevitable, i.e., group lesson planning.

The following transcripts qualify the claim of the study that the provisions of the Project KINANG developed collaboration among the pre-service secondary school teachers:

Informant 5. “... na-heighten yung collaboration sa amin kasi grupo kami na gumagawa ng plan... tulongtulong kami na mag-isip ng strategies...”

"Collaboration among us is heightened. We collectively thought of strategies..." 
Informant 8. “... uhm... kunwari ngayon, kasi stress ka din sa klase, di ka makagawa ng LP tapos nagtanong ka sa grupo about sa lesson. Ganito ang gawin mo dyan! Ganito yan... tapos ganito para mas exciting yung klase ganon ... uhm ... collaborative yung work..."

"We worked collaboratively with our groupmates. We kept on suggesting ways (strategies and activities) to make our plan better..."

Informant 6. “... nagtatanungan kami ng kung paano i-develop yung lesson, mga strategies ganon at mga activities ..."

"I asked and share ideas on lesson development, strategies, and activities..."

Informant 3. “... doon kasi sa office na ibinigay sa amin e ginawa namin na U-shape. Nagtutulungan kami kung paano mapagagaan yung work lalo na noong una. Hirap kami na mag-LP..."

"We had difficulty in lesson planning so we kept on helping each other..."

Informant 4. “... Malaki ang naitulong non kasi hindi lang ikaw ang gumagawa ng LP. May share ang lahat. Sama-sama kami na mag-LP...”

"Everybody had a share. We worked altogether in lesson planning..."

Informant 10. “...Nagtutulungan kami ganun, nagshi-share ng mga ideas on strategies and techniques sa mga ka-majors. Ang ganda ng mga suggestions; natuto ako...”

"We helped each other by sharing our ideas. I learned from their suggestions..."

Avenue to learn new ideas. The Social Learning Theory explicates the encounter of learners to functional learning sessions. Ideas presented in group discussions are propagated by a healthy discussion followed by assimilation. Members adopt new ideas which they see as a good, potential practice.

The following transcripts qualify the claim of the study that the provisions of the Project KINANG provided avenues to learn new ideas:

Informant 1. “... syempre yung sa group lesson planning e nadadagdagan yung mga ideas mo. Nakapupulot ka ng mga strategies dun sa mga suggestions nila. Mas madali ang mag LP...”

"Your ideas are improved in group lesson planning because you get better options from their suggestions. Lesson planning is made easier..."

Informant 2. “... nai-tatanong namin yung mga hindi namin kabisadong gawin like mga strategies, activities na hindi ko alam. May mga alam ako na hindi nila alam - or yung mga alam na nila na hindi ko alam. So natututo kami..."

"We got a group whom we can ask on things that we are not certain like employing strategies and activities.

Informant 3. “... sa group lesson planning e nakapagbabahagi ka ng mga ideas mo on the content and strategies. So we learn from each other...”

"We learn from each other as we share our ideas on the content and strategies whenever we do GLP..."

Informant 4. “... natututo kami sa sharing ng mga kasama namin on their effective teaching. It is more on (tawag dito) sharing of ideas..."

"We learned from the sharing of our groupmates on effective teaching..."

Informant 10. “...Nagtutulungan kami ganun, nagshi-share ng mga ideas on strategies and techniques sa mga ka-majors. Ang ganda ng mga suggestions; natuto ako...”

"We helped each other by sharing our ideas. I learned from their suggestions..."

Adaption and Innovation. Learners, when motivated and exposed to favorable and connected learning opportunities, will most likely to adapt things that motivate them to do better. When challenged by the ideas of others, learners will form an internal schema that will build their vista on innovating a unique idea. In this way, they self-actualize, adapt, innovate, and profess. Hence, innovation is coined from their motivating learning encounters.

The following transcripts qualify the claim of the study that the provisions of the Project KINANG made the informants to adapt and innovate something: 
Informant 9. “...nakakapag-adapt ka ng strategy mula sa kasama mo... mag-i-innovate ka mula don sa mga sinabi niya (nila)...”

"You can adapt strategies from your groupmates and then you innovate..."

Informant 7. “...maganda kasi nga e pwede kang mag-adapt tapos sasabihin mo sa sarili mo e dapat gagawa ka ng sairili mong version ng mga sinabi nila para parang hindi ka nangopya (smiles)..."

"It was good. I was able to adapt and innovate something so they will not say that I cheated..."

\section{Discussion}

1. Quantitative Analysis on the Effects of Project KINANG on the Individual Innovativeness of Pre-service Secondary School Teachers

Teachers who infuse innovations in their classes are most likely to produce innovative learners. Innovation, in this sense, is regarded as an idea, practice, or object that is perceived as new by an individual or other unit of adoption. Individual innovativeness is, therefore, defined as developing, adopting, or implementing an innovation. Hence, there is always new information within the niche of the individual or social system and that this new information is processed by adopters (Davis et al., 2010; Nutley et al., 2002; Oliver \& Goerke, 2008; Rogers, 2003; Yuksel, 2015;).

In this study, innovation centers the idea of infusing changes in the classroom that calls for the creativity of every teacher. Also, it calls for the ability of every teacher to introduce novel ideas that may develop the sense of innovation among learners. The increased innovation index among the pre-service teachers as reflected in Tables 4 and 5 shows that the Intervention Program is effective. Moreover, the effect size shown in Table 5 is also convincing.

In the Theory of Individual Innovativeness, it is stipulated that it is based on who adopts the innovation and when. It was noted that individual innovativeness is apportioned at the individual level in a variety of external or social conditions that may accelerate or slow the diffusion process: (1) Whether the decision is made collectively by individuals or by a central authority; (2) The communication channels used to acquire information about an innovation, whether mass media or interpersonal; (3) The nature of the social system in which the potential adopters are embedded (as identified by its norms) and the degree of interconnectedness; and (4) The extent of change agents' promotion efforts advertisers, development agencies, among others (Rogers, 2007; Hammond et al., 2011; Su Eroz, 2017; Yuksel, 2015).

Aptly, the qualitative data revealed in section 2 of the results show the magnitude of the pre-service secondary school teachers' experiences and encounters that advanced their vista on becoming innovative teacher-researchers. Hence, the purposes of employing the Project KINANG were attained.

2. Qualitative Analysis on the Effects of Project KINANG on the Individual Innovativeness of Pre-service Secondary School Teachers

The affordances of the pre-service secondary school teachers on their innovativeness are encroached by the idea that they need to be shaped to something definite which may start from a well-rounded activity that can polevault their enthusiasm, motivation, and cognition. When realized, their curiosity to pursue excellence in their performances is expected. In the case of the pre-service secondary school teachers in this study, a start-up to set the mood of becoming an innovative teacher-researcher was provided. This started from an action sequence that advanced their learning from their academic experiences and encounters. In this study, the start-up was the Pinning Ceremony, LAC Sessions, and Action Research Expo.

The provisions of the Project KINANG were believed to emancipate the enthusiasm, motivation, and cognition of the pre-service secondary school teachers. It started with a jump-start activity to boost their self-determination and self-regulation that reciprocated their vista on what it takes to be a $21^{\text {st }}$ century teacher: an innovative teacherresearcher.

Research findings revealed that teachers who are intrinsically motivated are the individuals who have high sense of self-determination (Eggen \& Kauchak, 2008; Omrod, 2004). Moreover, the individuals who exude high sense of self-regulation are most likely to become intrinsically motivated to perform better because they set their goals and standards, monitor their progress, and evaluate their performances (Omrod, 2004; Lucas \& Corpuz, 2014; Soffer et al., 2010). Hence, a motivated teacher is curious, flexible, insightful thinker, and innovative: all these and more are characteristics of a teacher-researcher. Also, these teachers must be in a gamut of functional groups from which they can find a collaborator, advisor, and mentor.

Relating the provisions of the Project KINANG to the enthusiasm of the pre-service secondary school teachers, they are exposed to learning opportunities that enhance positive emotions, commitment to quality teaching and 
learning, strategic effort along persistence over time that revitalized their perceptions to interesting and personally relevant tasks; hence, transforming every task that propagates innovation among the classes of these pre-service secondary school teachers (Ali, 2017; Su Eroz, 2017; Hammond et al., 2011).

The crux is: the courses of actions, as well as the exposure of pre-service teachers to become innovative, must revitalize their vista on reinventing classroom teaching and learning.

\section{Conclusion}

Based on the findings and parameters of the study, the following are drawn:

1. Respondents, through the Project $K I N A N G$, were advanced to early adopters and early majority. It diminished the late majority and eliminated the laggards or traditionalists;

2. There was an increased innovation index among the pre-service secondary school teachers; hence, a significant increased at .05 level of significance;

3. The Project KINANG posted medium effect on the innovation index of pre-service secondary school teachers; and

4. The Project KINANG provided learning experiences and encounters that were morale boosting and motivating; hastening task management, teaching effectiveness, curiosity, and innovation; inspiring the preservice secondary school teachers to become researchers; improving the pre-service secondary school teachers' communication skills; heightening collaboration that provided them avenues to learn new ideas.

\section{Recommendation}

The increased innovation index and the documented experiences and encounters of the pre-service secondary school teachers showed that there is a need to provide a jump-start activity that would pole-vault their enthusiasm, motivation, and cognition. In doing so, they would be motivated to discharge their duties and responsibilities at par during their student teaching. A heightened Pinning Ceremony, LAC Sessions with their professor, and Action Research Expo may be offered to the next batch of BSEd students who will be having their Student Teaching this SY 2019-2020. The CTE may ensure that its next batch of Student Teachers will be equipped with much readiness and motivation through a committed professor who is willing to do an extra mile so they may bring out the best version of themselves.

\section{References}

Ali, A. (2003). Faculty adoption of technology: Training comes first. Educational Technology, 43, 51-53

Ali, I. (2017). Personality traits, individual innovativeness, and satisfaction with life. Journal of Innovation and Knowledge, in press. http://doi.org/10.1016/j.jik.2017.11.002

Anderson, J. (2010). ICT Transforming Education: A Regional Guide. Bangkok: UNESCO.

Anderson, T., Varnhagen, S., \& Campbell, K. (1998). Faculty adoption of teaching and learning technologies: Contrasting earlier adopters and mainstream faculty. The Canadian Journal of Higher Education, 28(23),7178.

Ajzen, I. (1991). The theory of planned behavior. Organizational Behavior and Human Decision Processes, 50, $179-211$.

Bautista, RG., Valdez, CGT., Garingan, EG., Camayang, JG., Horlador, DNP., Manait, JN., and Reyes, ES. (2018). Individual innovativeness of pre-service elementary grade teachers. American Journal of Educational Research, 6 (6), 617-620.

Bandura, A. (1986). Self-efficacy: The Exercise of the Control. New York: WH Freeman and Company

Celik, K. (2013). The relationship between individual innovativeness and self-efficacy level of student teachers. International Journal of Scientific Research in Education, 6 (1), 56-67.

Cocklar, A. (2012). Individual Innovativeness Levels of Educational Administrators. Digital Education Review: http://greav.ub.edu/der

Davis, H., Hartshorne, R., \& Ring, G. (2010). Being an innovative teacher: Pre-service teachers' conceptions of technology and innovation. International Journal of Education, 2(1), 1-28. http://dx.doi.org/10.5296/ije.v2i1.242

Eggen, P. \& Kauchak, D. (2008). Educational Psychology: Windows on Classroom. Ohio: Pearson Co.

Hammond, M.M., Neff, N.L., Farr, J.L., Schwall, A.R., \& Zhao, X. (2011). Predictors of individual-level innovation at work: A meta-analysis. Psychology of Aesthetics, Creativity, and the Arts, 5(1), 90-105.

Hurt, H. T., Joseph, K., \& Cook, C. D. (1977). Scales for the measurement of innovativeness. Human Communication Research, 4, 58-65. http://dx.doi.org/10.1111/j.1468-2958.1977. tb00597

Kilicer, K. \& Odabasi, H. (2010). Individual innovativeness scale: the study of adaptation to Turkish validity and reliability. Hacettepe University Journal of Education, 38, 150-164.

Lucas, M.R.D. \& Corpuz, B.B. (2014). Facilitating Learning: A Metacognitive Process. Quezon City: Lorimar Publishing, Inc. 
Nutley, S., Davies, H., \& Walter, I. (2002). Conceptual synthesis 1: Learning from the diffusion of innovation. http://www.st-andrews.ac.uk/ cppm/Learning\%20from\%20the\%20Diffusion\%20of\%20innovations.pdf

Oliver, B. \& Goerke, V. (2008). Undergraduate students' adoption of handheld devices and Web 2.0 applications to supplement formal learning experiences: Case studies of Australia, Ethiopia and Malaysia. International Journal of Education and Development Using ICT, 4(3), 78-94.

Omrod, J.E. (2004). Educational Psychology: Developing Learners. New Jersey: Prentice Hall Inc.

Parlar, H. \& Cansoy, R. (2017). Examining the Relationship between Teachers' Individual Innovativeness and Professionalism. International Education Studies, 10 (8) 1913-9020.

Parminter, T. \& Wilson, J. (2003). Systematic intervention in biodiversity management based upon the theory of reasoned action. Proceedings of the 1st Australian Farming Systems Association Conference.

Rogers, E.M. (1995). Diffusion of Innovations. New York: Free Press.

- ibid (2004). A prospective and retrospective look at the diffusion model. Journal of Health Communication, 9, 13-19. http://dx.doi.org/10.1080/10810730490271449

- $\quad$ ibid (2003). Diffusion of Innovation (5th ed.). New York: Free Press.

Soffer, T., Nachmias, R., \& Ram, J. (2010). Diffusion of web supported instruction in higher education - The Case of Tel-Aviv University. Educational Technology \& Society, 13(3), 212-223

Su Eroz, S. (2017). The relationship between individual innovativeness and locus of control: A research on tourism faculty and students. Journal of Tourism and Hospitality Management, 5 (1), 46-52.

Yates, B. (2001). Applying diffusion theory: adoption of media literacy programs in schools. Conference Paper: International Communication Association Conference.

Yuksel, I. (2015). Roger's Diffusion of Innovation Model in Action: Individual Innovativeness Profiles of Preservice Teachers in Turkey. Croatian Journal of Education, 17 (2), 507-534. http://dx.doi.org/10.15516/cje.v17i2.871 